\title{
Reaction to release treatments and distinctive attributes of butternut that promote resistance to the canker caused by Ophiognomonia clavigignenti-juglandacearum
}

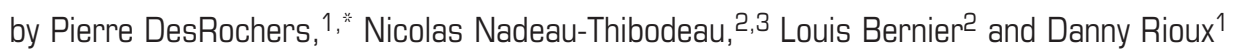

\begin{abstract}
This research examines the impact of light and tree attributes of butternuts, including bark phenotype, on their health. Some butternuts were released by thinning the crowns of neighbouring trees in two locations in Québec, while others were not. Various butternut characteristics related to their health that had been collected by a partner in the Montérégie region are also analysed. The release treatment did not have any significant impact on any health variables. However, their location, the diameter increments before releasing trees and twig collection on some butternuts had a significant impact on some of these variables. For the butternuts of the Montérégie region, their position in the canopy had a significant impact on main stem damage and on the putative resistance to the canker caused by Ophiognomonia clavigignenti-juglandacearum; trees from the upper storey were healthier. Dieback of dark and deep furrowed bark phenotype butternuts was significantly lower than that of the light, shallow furrowed bark ones. Butternuts with a greater annual increase in basal area had better vigour. This was greater in the upper canopy and among the deep furrowed bark butternuts.
\end{abstract}

Keywords: butternut, Ophiognomonia clavigignenti-juglandacearum, release, canker, resistance, dieback, vigour, growth increment, bark phenotype, storey, basal area

\section{RÉSUMÉ}

Nous examinons l'impact du dégagement et des caractéristiques des noyers cendrés, y compris le phénotype d'écorce, sur leur santé. Sur deux sites au Québec, des noyers ont été mis en lumière par détourage de cime. Nous analysons aussi les caractéristiques de noyers recueillies par un collaborateur en Montérégie en lien avec leur santé. Il n’a pas été démontré que ce dégagement améliorait la santé des noyers. Cependant, le site, la croissance en diamètre avant le dégagement et le prélèvement de rameaux sur certains noyers ont eu un impact significatif sur certaines variables de santé. Concernant les noyers cendrés de la Montérégie, les dommages au tronc et la résistance potentielle au chancre causé par l'Ophiognomonia clavigignenti-juglandacearum sont influencés de façon significative par l'étage auquel ils appartiennent, une position supérieure garantissant une meilleure santé. La mort en cime des noyers de phénotype à écorce foncée et rugueuse est significativement moindre que celle des noyers à écorce lisse. La vigueur des noyers est supérieure chez les arbres présentant une plus grande croissance annuelle en surface terrière. Cette croissance annuelle est significativement plus élevée chez les noyers des étages supérieurs et chez les noyers cendrés à écorce rugueuse.

Mots clés : noyer cendré, Ophiognomonia clavigignenti-juglandacearum, dégagement, chancre, résistance, mort en cime, vigueur, croissance radiale, phénotype d'écorce, étage, surface terrière

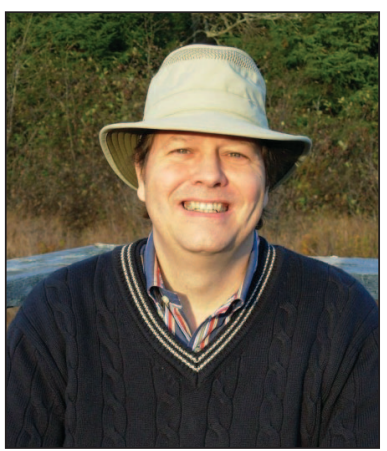

Pierre DesRochers

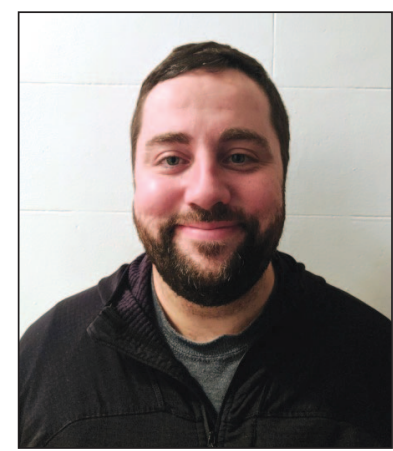

Nicolas Nadeau-Thibodeau

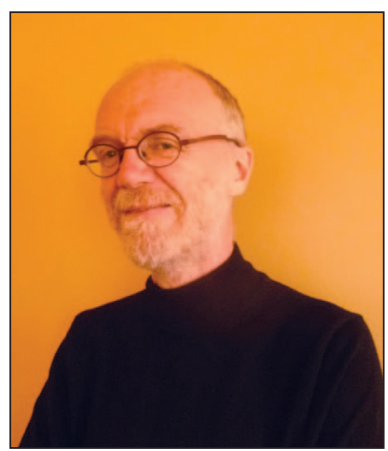

Louis Bernier

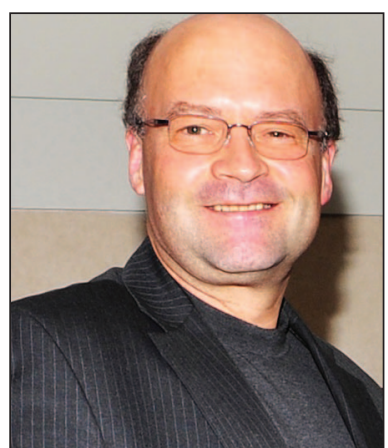

Danny Rioux

\footnotetext{
${ }^{1}$ Laurentian Forestry Center, Canadian Forest Service, Natural Resources Canada, 1055 du P.E.P.S., P.O. Box 10380, Sainte-Foy Stn., Quebec, QC G1V 4C7; *Author of correspondence: pierre.desrochers@canada.ca, pierredesroc@gmail.com

${ }^{2}$ Centre for Forest Research, Faculty of Forestry, Geography and Geomatics, Université Laval, Québec, QC G1V 0A6, Canada

${ }^{3}$ Current address: City of Montréal, Plateau-Mont-Royal Borough, 201 Laurier Avenue East, H2T 3E6
} 


\section{Introduction}

Butternut is a minor component of the deciduous forests in the valleys of the St. Lawrence River, the Ottawa River and the Great Lakes (Grandtner 1966). In Québec, the most northerly known location is at Tapani Lake, northeast of the Baskatong Reservoir (Majcen 1995). The species is also found in New Brunswick (Farrar 1995) and in some 30 American states (Rink 1990). In Québec, it generally grows in forest associations such as sugar maple-hickory, basswood-sugar maple, and yellow birch-sugar maple (Lupien 2013), where it is either isolated or in small groups, making up 3\% or less of the forest cover (Grandtner 1966). It occasionally forms small stands in which it occupies up to half of the basal area, but usually only in high and medium tree strata (Majcen 1995). However, even when stands have a high proportion of butternuts, they are generally absent from the lower tree and shrub layers (Majcen 1995) or regeneration strata (Grandtner 1966). In fact, the lack of light impedes the regeneration of this medium-sized, relatively short-lived species (75 years) which does not tolerate shade (Rink 1990; Niinemets and Valladares 2006).

In addition to the limited light in the lower strata, several pests threaten the health and survival of the butternut. As early as 1923, Graves (1923) identified cankers caused by Melanconis juglandis (Ellis \& Everh.) A.H. Graves as causing a slow dieback of the species. The butternuts that are most sensitive to this pathogen are those that are less vigorous, especially those in shade (Graves 1923). Other pests may affect the health and survival of this species: anthracnose caused by Marssonina juglandis (Lib.) Magnus. and defoliators such as the fall webworm (Hyphantria cunea Drury), the walnut shoot moth (Acrobasis demotella Grote) and the walnut caterpillar (Datana integerrima Grote \& Robinson) that reduce the photosynthetic capacity of butternuts, their vigour and their ability to respond to stress (Farris and Appleby 1979; Nielsen et al. 2003; Environment Canada 2010). Other pests specifically target woody tissue, including root rot caused by Armillaria gallica H. Marxm. \& Romagn., butternut curculio (Conotrachelus juglandis Lec.), and Phomopsis and Fusarium cankers (Corneil and Wilson 1979; Rink 1990; Nielsen et al. 2003; Environment Canada 2010), resulting in twig and branch mortality.

However, butternut canker caused by Ophiognomonia clavigignenti-juglandacearum (Nair, Kostichka \& Kuntz) Broders \& Boland remains the greatest threat to the species (Nair et al. 1979; Environment Canada 2010; Broders and Boland 2011). It was first discovered in Wisconsin in North America in 1967 (Ostry and Woeste 2004), and detected in Québec in 1990 (Innes and Rainville 1996), in Ontario in 1991 (Davis et al. 1992) and in New Brunswick in 1997 (Harrison et al. 1998). Although the origin of the fungus is unknown, its low genetic variability and its virulence suggest that it is an exotic pest (Furnier et al. 1999). Recent studies also show that the population of $O$. clavigignenti-juglandacearum consists of three different groups of isolates corresponding to three separate introductions, or isolates that evolved from avirulent forms on butternut (Broders et al. 2012).

The fungus first invades twigs, buds, lenticels and/or bark wounds (Kuntz et al. 1979; Ostry 1997; Sinclair and Lyon 2005). The twigs wither and become covered with stro- matic columns that produce conidia capable of infecting the branches and trunks of their host and neighbouring butternuts. The crowns of infected trees display an increasing proportion of dry twigs. As the infection of the bole progresses, trees weaken and die. Some authors have reported the possible existence of a phenotype of butternuts which is resistant to O. clavigignenti-juglandacearum (Ostry et al. 2003; Michler et al. 2006). These butternuts have a darker bark with deeper crevices. According to Boraks and Broders (2014), although shallow-barked butternuts had proportionately more trunk damage than those with rough and deep furrowed bark, this difference could be the result of the smaller diameter of the smooth-barked butternuts. Finally, the increasing mortality of butternuts led Environment Canada to declare the species endangered in 2005 (Environment Canada 2010). A butternut recovery strategy was made public in 2010 by Environment Canada.

The program set out the following objectives: "By 2019, address priority knowledge gaps and research necessary for implementing recovery activities (including research into disease resistance and level of adaptive genetic variation, as well as environmental factors that limit the spread of the disease)." The disease in question is the canker caused by O. clavigignenti-juglandacearum, which we will refer to simply as "the canker" in the rest of this paper.

There are silvicultural recommendations for butternut (Lupien 2006), but they promote the production of quality wood and the establishment of regeneration. Ostry et al. (1994) set out recommendations for the conservation of potentially resistant butternuts: conserving butternuts without damage to their trunk and less than 50\% crown death, as well as those with less than $30 \%$ crown death but less than $20 \%$ of the circumference of the trunk affected by the canker. McIlwrick et al. (2000) recommended removing dead butternuts as soon as possible, given their ability to transmit $O$. clavigignenti-juglandacearum to healthy butternuts in their vicinity. Silvicultural practices have been recommended to reduce the impact of different cankers, either by releasing or pruning. Amorini et al. (2001) demonstrated that thinning vegetation around healthy chestnuts reduced the prevalence of the canker caused by Cryphonectria parasitica (Murrill) M.E. Barr. A similar observation was made with respect to mortality caused by various aspen diseases, with the exception of Hypoxylon canker (Pitt et al. 2001). There are also several publications on the beneficial effects on the health and survival of affected trees brought about by pruning cankered twigs (Abgrall and Soutrenon 1991; Laflamme 1999; Weber 2014; Jacobi et al. 2017). We did not find any such studies on butternut. Given its intolerance to shade (Niinemets and Valladares 2006), access to light may influence the resistance to canker. In fact, preliminary data collected during an inventory conducted from 2006 to 2008 (DesRochers et al. 2010) suggested that trees growing in the open or in the upper canopy were healthier than trees growing in shade. In this context, the objectives of this study are to:

1. Examine the impact of crown release, increasing the access to light, on butternut health variables and resistance to canker; and,

2. Alternatively, examine the influence of other tree features of butternut on their health, in particular the bark phenotype. 


\section{Materials and methods}

The studies

In this paper we report on the results of two studies. First, an experiment was carried out in 2011 whereby butternuts were released so that the light to which they were exposed to was increased. Second, we analysed the data collected by a collaborator in Montérégie, CIME Haut-Richelieu between 2005 and 2016.

The release experiment to increase access to light was carried out at two sites in Quebec, i.e., at the Université Laval Agronomy Station in Saint-Augustin-de-Desmaures and at the National Defence range at Mont Saint-Bruno. The butternuts selected for this experiment were all in the overstorey or the co-dominant layer, with the exception of one butternut which was classified as intermediate. At each site, 20 butternuts which were potentially resistant (Ostry et al. 1994) to O. clavigignenti-juglandacearum were selected. In 2010, the dieback of the selected butternuts ranged from zero to $10 \%$, aside from one that was rated with $20 \%$ dieback. Trunk damage was either null or less than $25 \%$ of the butternut circumference. Butternuts from Mont Saint-Bruno had a mean diameter at breast height $(\mathrm{DBH})$ of $39.9 \mathrm{~cm}$ with a standard error of $9.9 \mathrm{~cm}$ (range from $17.5 \mathrm{~cm}$ to $57.8 \mathrm{~cm}$ ). Those from the Agronomy Station had a mean DBH of $39.6 \mathrm{~cm}$ with a standard deviation of $7.7 \mathrm{~cm}$ (range from $27.8 \mathrm{~cm}$ to 61.2 $\mathrm{cm})$. The pooled data for these two locations are shown by crown class in Table 1. Two treatments were randomly applied among the selected trees in each site: 10 were controls and 10 were subjected to release by pruning neighbouring trees (détourage de cime) to increase the exposure to light (Lupien 2006). Control trees were not subjected to release treatments. For butternuts undergoing release treatments, the tops of neighbouring trees were pruned to clear a space free of branches spanning 5-m around their crowns. This opening of the crowns was visually acceptable for the numerous visitors and soldiers that would visit Mont Saint-Bruno year round. This work was done between January 20 and March 31, 2011. One butternut from Mont Saint-Bruno and one from the Agronomy Station, both control trees, were excluded from the assessments and analysis because they were uprooted or badly damaged by the storm that followed Hurricane Irene in 2011. The health of the trees was monitored annually until 2016. We will analyze the 2016 health data for both treatments. After the experiment was laid out, it was also used by Tanguay et al. (2018) for their study of the conidia production in O. clavigignenti-juglandacearum.
Tests were carried out on 65 butternut trees growing in the wild in Québec (unpublished results) and none showed signs of hybridization with Japanese walnut (J. ailantifolia Carr.). Such hybrids are deemed more resistant to the canker (Orchard et al. 1982) and thus it was desirable to evaluate the absence of hybrids among the 200 butternut trees we had identified as potentially resistant to the canker on different sites in Québec (Nadeau-Thibodeau 2015). More specifically, even if all the trees were not assessed, 10 trees have been analyzed at both sites (Mont Saint-Bruno and the Agronomy Station), of which six were assessed simultaneously using four microsatellite markers (J.A. McLaughlin and G. Halicki, Ontario Ministry of Natural Resources and Forestry, unpublished results), and by genotyping-bysequencing (N. Isabel and M. Lamothe, LFC, unpublished results). No hybridization was revealed. In addition, we examined the morphology of twigs collected on the 19 trees of the cutting experiment described in the following section and all only showed morphological characters specific to butternut (Woeste et al. 2009).

Another experiment was carried out concurrently on several of the butternuts in this study, given the limited number of trees, in order to use the available technical staff to the best advantage. For the purposes of this experiment, 30 to 45 healthy, dormant twigs were harvested from each of 13 control butternuts and six released butternuts, all randomly selected, to provide cuttings. These butternuts were distributed equally between the two sites (Nadeau-Thibodeau 2015; Rioux et al. 2019). In addition, dead wood was removed to facilitate access to healthy twigs at the top of the crowns.

Data on the growth and health of butternut were collected by CIME Haut-Richelieu collaborators from 85 trees for several successive years between 2005 and 2016 at Mont SaintGrégoire and on private land in Saint-Jean-sur-Richelieu in the Montérégie region. The $\mathrm{DBH}$ of these trees was measured during the initial assessment (Table 2) and a second time a few years later. The interval between the two measurements varied from two to seven growing seasons, depending on the sites monitored. We analyzed the health data from the last year in which the DBH was measured. The mean DBH of the butternuts rated by CIME Haut-Richelieu was $20.9 \mathrm{~cm}$ with a standard deviation of $15.8 \mathrm{~cm}$ at their first measurement. The DBH of light gray, intermediate and rough bark phenotypes were $19.9 \mathrm{~cm}, 18.8 \mathrm{~cm}$ and $29.5 \mathrm{~cm}$, respectively. Their respective standard deviations were $11.1 \mathrm{~cm}, 11.8 \mathrm{~cm}$ and $22.1 \mathrm{~cm}$.

Table 1. Diameter at breast height of the butternuts used in the release experiment, according to the storey in which they belong, as measured before the treatment in 2010

\begin{tabular}{lccccc}
\hline & & \multicolumn{3}{c}{ DBHi (cm) } \\
\cline { 3 - 5 } Story $^{\mathrm{a}}$ & Number & Minimum & Maximum & Mean & Standard error \\
\hline Overstory and open grown & 19 & 26.7 & 61.2 & 43.8 & 8.6 \\
Codominant and intermediate & $18^{\mathrm{b}}$ & 17.5 & 47.0 & 35.7 & 6.9 \\
\hline
\end{tabular}

${ }^{a}$ As the number of butternuts is low, overstorey and open grown trees were pooled, as well as codominant and intermediate butternuts

bone data missing 
Table 2. Initial diameter at breast height (DBHi) of the butternuts assessed by CIME Haut-Richelieu according to the number of growing seasons and bark phenotype

\begin{tabular}{lccccc}
\hline & & \multicolumn{3}{c}{ DBHi (cm) } \\
\cline { 3 - 5 } Feature & Number & Minimum & Maximum & Mean & $\begin{array}{c}\text { Standard } \\
\text { deviation }\end{array}$ \\
\hline Seasons & & & & & \\
$\quad$ Two & 3 & 6.8 & 15.0 & 10.9 & 4.1 \\
$\quad$ Three & 4 & 10.8 & 22.0 & 15.4 & 4.8 \\
Four & 60 & 0.5 & 95.2 & 19.9 & 16.7 \\
Five & 13 & 2.9 & 44.3 & 24.5 & 12.3 \\
Six & 1 & - & - & 20.7 & 16.8 \\
Seven & 4 & 14.6 & 54.5 & 37.6 & \\
Bark phenotype & & & & & 11.1 \\
$\quad$ Smooth & 24 & 2.9 & 44.5 & 19.3 & 11.8 \\
Intermediate & 38 & 0.5 & 47.1 & 16.8 & 22.1 \\
$\quad$ Rough & 23 & 5.0 & 95.2 & 29.5 & \\
\hline
\end{tabular}

\section{Mensuration variables}

The following variables were evaluated: diameter at breast height $(\mathrm{DBH})$ and the canopy layer to which the tree belonged. Radial growth increment from 2005 to 2010 was calculated for all the butternuts in the release experiment. Basal area growth was calculated using the DBH for butternuts assessed by CIME Haut-Richelieu.

DBH was measured in centimeters and tenths of centimeters with a circumference tape at a height of $1.3 \mathrm{~m}$ above the ground according to the Acid Rain National Early Warning System (ARNEWS; D’Eon et al. 1995).

The location in the canopy, or dominance, was measured according to the ARNEWS methodology (D'Eon et al. 1995). Trees were ranked as dominant (value 1) if they were in the open or were located in the upper canopy and received light from above and from the sides; codominant trees (value 2) received light mainly from the top; intermediate trees (value 3) were smaller than co-dominant trees and received little light, while suppressed trees (value 4) were entirely under the forest canopy.

Pre-treatment radial growth was calculated in $\mathrm{mm}$ for each butternut for 2005 to 2010, inclusively. In the fall of 2013, 20 released butternuts and 18 control butternuts in the release experiment were sampled to assess pre-treatment growth. One core sample per tree was collected at DBH and the wound later plugged with grafting wax (Orchard and Nursery Grafting Wax, Dilmont Inc., Montréal, P.Q, Canada) to limit risk of infection with $O$. clavigignenti-juglandacearum. The core samples were digitized (Epson Perfection V600 Photo Scanner) at a resolution of 2400 DPI, and the annual rings measured using CooRecorder software and cross dated with CDendro (version 7.6).

The annual increment in basal area before the final rating was calculated from the butternut DBH rated by CIME HautRichelieu. The initial basal areas $\left(\mathrm{BA}_{\mathrm{i}}\right)$ and final basal areas $\left(\mathrm{BA}_{\mathrm{f}}\right)$ of the 85 butternuts evaluated by CIME Haut-Richelieu were calculated from the initial $\mathrm{DBH}\left(\mathrm{DBH}_{\mathrm{i}}\right)$ and the final $\mathrm{DBH}\left(\mathrm{DBH}_{\mathrm{f}}\right)$, respectively, using the following formulas:
[1]

[2]

$$
\begin{aligned}
& \mathrm{BA}_{\mathrm{i}}=\pi\left(\mathrm{DHP}_{\mathrm{i}} / 2\right)^{2} \\
& \mathrm{BA}_{\mathrm{f}}=\pi\left(\mathrm{DHP}_{\mathrm{f}} / 2\right)^{2}
\end{aligned}
$$

The annual increase in basal area $\left(\Delta \mathrm{BA}_{\mathrm{y}}\right)$ was calculated using the following formula:

$$
\text { [3] } \quad \Delta \mathrm{BA}_{\mathrm{a}}=\left(\mathrm{BA}_{\mathrm{f}}-\mathrm{BA}_{\mathrm{i}}\right) / \mathrm{Y}
$$

where, $\Delta \mathrm{BA}_{\mathrm{y}}$ is the number of years of growth between the two DBH measurements.

The overstorey is an ordinal variable while radial growth increment and annual basal area increment are continuous variables.

\section{Health variables}

The following variables were evaluated: crown dieback, proportion of trunk with cankers, and vigour. Potential resistance to canker was calculated based on crown dieback and proportion of cankered trunk.

Crown dieback is the mortality of twigs and branches starting from the end of the twigs towards the branches and then the trunk. It was assessed visually by examining twigs and branches $\leq 2.5 \mathrm{~cm}$. Crown dieback was assessed for each butternut of both studies by one or two crown raters according to the 12 categories of the North American Maple Project (Millers et al. 1991): $0 \% ; 1 \%$ to $5 \%$; $6 \%$ to $15 \% ; 16 \%$ to $25 \%$; $26 \%$ to $35 \%$; $36 \%$ to $45 \%$; $46 \%$ to $55 \%$; $56 \%$ to $65 \%$; $66 \%$ to $75 \%$; $76 \%$ to $85 \%$; $86 \%$ to $95 \%$, and $96 \%$ to $99 \%$, but also included dead trees (100\%) in the $96-99 \%$ class. Snags without twigs measuring $2.5 \mathrm{~cm}$ or less in diameter were not considered. Dried twigs in the shaded area below the crown were presumed to have died due to natural pruning and are not included in the assessment.

The cankered portion of the trunk was evaluated by adding together the cankered portions of the trunk and the root flare of the butternut expressed as a percentage, and grouped according to the following categories: 0 , no damage; 1 , dam- 
age to $25 \%$ or less of the circumference; 2 , damage to $26-50 \%$ of the circumference; 3 , damage to $51-75 \%$ of the circumference; 4 , damage to over $75 \%$ of the circumference. This assessment is a modification of that proposed by Ostry et al. (1994) who set categories at ranges of $20 \%$ rather than $25 \%$.

Potential resistance was calculated according to the criteria defined by Ostry et al. (1994), but taking into account the modification concerning damage to trunks. A butternut is considered to be potentially resistant (category 1) if it does not show any damage to its trunk and has crown dieback of less than $50 \%$, or if the cankered proportion of the trunk is $25 \%$ or less and crown dieback is less than $30 \%$. In all other cases, the tree is considered vulnerable to canker (category 0 ).

The vigour of butternuts in both studies was also measured using the North American Maple Project method (Millers et al. 1991). This is an overall assessment of all causes of crown damage, including snags, dead branches and broken branches. Trees are classified as healthy (class 1 ) if they are less than $10 \%$ damaged; lightly declining (class 2 ) if 10 to $25 \%$ of their crown suffers damage; moderately declining (class 3 ) if the damage affects between 26 and $50 \%$ of the crown; severely declining (class 4 ) if $51 \%$ or more of the crown is damaged; and dead (class 5) if the entire crown is damaged and without foliage.

Potential resistance is a binary variable while the other three health variables are ordinal variables.

According to Ostry et al. (2003), butternut has two bark phenotypes. The first has a smooth, light grey bark with narrow, shallow crevices. The second has a rough, dark bark with deep crevices. They hypothesized that this second phenotype with the rougher bark was linked to increased resistance to butternut canker. In addition, our observations showed that there was an intermediate bark phenotype between the two described by Ostry et al. (2003). This is an ordinal variable. We considered the twig sampling globally (dormant twig cuttings, see above), rated as 1 for the trees with 30 to 45 twigs harvested and 0 for the butternuts without twig collection, and twig sampling was used as a covariable in the release experiment.

\section{Statistics}

The health variables in the release experiment were analyzed by stepwise logistic regression analysis (LOGISTIC procedure from SAS) using a probability for entrance into the model of 0.10 , and of 0.055 for the removal of variables already entered into the model (Stokes et al. 1995). Each of the four health variables was used individually as a dependent variable $\left(\mathrm{V}_{\mathrm{d}}\right)$, and the site (Saint-Augustin, Mont SaintBruno) as well as the treatment (released or control) were independent variables. Sampling was used as covariate. The interactions of these variables (two-by-two) have been included in the model as follows:

$$
\begin{aligned}
& \mathrm{V}_{\mathrm{d}}=\text { Site Treatment Sampling Site }{ }^{\star} \text { Treatment } \\
& \text { Site }^{\star} \text { Sampling Treatment }{ }^{\star} \text { Sampling }
\end{aligned}
$$

The relevance of the model was determined using the residual chi-squared test for which a probability greater than 0.05 indicates an appropriate model (Stokes et al. 1995). The effect of significant independent variables on each of the dependent variables was quantified using the odds ratio (SAS
Institute 2011). This ratio compares the impact of each independent variable on the dependent variable by assessing the greater or lesser probability that a butternut would be in a lower category of the ordinal dependent variable if the level (ordinal variable) or the rank (qualitative variable) of the independent variable was increased by one level or one rank. When the treatments were not significant, an alternative stepwise logistic analysis was performed using the phenotype and radial growth increment as dependent variables, and using the site and sample as covariates. The entrance and removal thresholds of the model remained the same, i.e., 0.10 and 0.055 .

Similarly, butternut health variables evaluated by the CIME Haut-Richelieu teams were subjected to a stepwise logistic regression analysis with the same entrance and removal thresholds for independent variables (Stokes et al. 1995) as in the release experiment. The overstorey, annual basal area increment, phenotype and two-way interactions among these three variables were used as independent variables. The relevance of the model and the effect of significant independent variables on each of the dependent variables were measured as before. For the three significant interactions with the phenotype, a non-stepwise logistic regression analysis was further used by phenotype.

To verify the hypothesis put forward by Boraks and Broders (2014) concerning the smaller diameter of smooth bark butternut, an analysis of the variance of the final DBH of the butternuts rated by CIME Haut-Richelieu was performed using the SAS GLM procedure (SAS Institute 2008) after the square root transformation of the $\mathrm{DBH}$ as follows:

$$
\sqrt{ }\left(\mathrm{DBH}_{\mathrm{f}}\right)=\text { Phenotype }
$$

This transformation of the $\mathrm{DBH}$ was done to ensure its normality. Orthogonal comparisons were also performed between the different phenotypes.

Finally, an analysis of the variance of the annual basal area increment $\left(\Delta \mathrm{BA}_{\mathrm{y}}\right)$ of the butternuts rated by CIME HautRichelieu was carried out using the SAS GLM procedure (SAS Institute 2008), after transforming the annual increment using the following equations:

$$
\begin{aligned}
& \sqrt{ }\left(\Delta \mathrm{BA}_{\mathrm{y}}\right)=\text { Storey Phenotype Store }{ }^{\star} \text { Phenotype } \\
& \sqrt{ }\left(\Delta \mathrm{BA}_{\mathrm{y}}\right)=\text { Storey Phenotype }
\end{aligned}
$$

The square root transformation of the annual increment was calculated to ensure its normality. The least square means of the dependent variable was calculated for each storey and phenotype value. Orthogonal comparisons were also performed between the different canopy levels and phenotypes.

\section{Results and discussion Release experiment}

The results of the stepwise logistic regression analysis of the health variables are presented in Table 3. No significant effects were detected for release treatments, regardless of the health variable examined. These results agree with those of Tanguay et al. (2018) who found insignificant differences between the conidial production of released trees and that of the controls. The logistic models for vigour and resistance are 
Table 3. Sequential logistic regression analysis of the health variables from the increased access to light experiment at Mont Saint-Bruno and the Universite Laval Agronomy Station based on release treatments

\begin{tabular}{|c|c|c|c|c|}
\hline \multicolumn{2}{|c|}{ Variables } & \multirow[b]{2}{*}{ Probability } & \multirow[b]{2}{*}{ Odds ratio $^{a}$} & \multirow{2}{*}{$\begin{array}{l}\text { Residual chi-square } \\
\text { probability }\end{array}$} \\
\hline Dependent & Independent & & & \\
\hline \multirow[t]{6}{*}{ Trunk damage } & Release & 0.40 & - & 0.67 \\
\hline & Site & 0.55 & - & - \\
\hline & Samples & 0.33 & - & - \\
\hline & Release x Site & 0.30 & - & - \\
\hline & Release x Samples & 0.78 & - & - \\
\hline & Site x Samples & 0.25 & - & - \\
\hline \multirow{6}{*}{ Crown dieback } & Release & 0.18 & - & 0.038 \\
\hline & Site & 0.0082 & 5.2 & - \\
\hline & Samples & 0.09 & - & - \\
\hline & Release x Site & 0.71 & - & - \\
\hline & Release x Samples & 0.48 & - & - \\
\hline & Site x Samples & 0.29 & - & - \\
\hline \multirow[t]{6}{*}{ Vigour } & Release & 0.46 & - & 0.12 \\
\hline & Site & 0.0009 & 12.6 & - \\
\hline & Samples & 0.0316 & 4.2 & - \\
\hline & Release x Site & 0.99 & - & - \\
\hline & Release x Samples & 0.76 & - & - \\
\hline & Site $\mathrm{x}$ Samples & 0.12 & - & - \\
\hline \multirow[t]{6}{*}{ Resistance } & Release & 0.38 & - & 0.48 \\
\hline & Site & 0.36 & - & - \\
\hline & Samples & 0.0271 & 0.16 & - \\
\hline & Release x Site & 0.28 & - & - \\
\hline & Release x Samples & 0.60 & - & - \\
\hline & Site $\mathrm{x}$ Samples & 0.84 & - & - \\
\hline
\end{tabular}

${ }^{a}$ The odds ratios are given only for significant independent variables $(\mathrm{P} \leq 0.05)$. A butternut growing at the Université Laval Agronomic Station has five (5.2) times more chances of being assessed in a lower class of dieback (e. g., 20\% or less) than one growing at Mont Saint-Bruno. In addition, this butternut has 13 (12.6) times more chances to be rated as vigorous as if it grew at Mont Saint-Bruno. Butternuts that were sampled for twigs have four (4.2) times more probability to be rated as vigorous and six times less (0.16) chances to be classified as sensitive to the canker than those that were not sampled.

appropriate, while the low probability for the residual chisquare of dieback shows that the identified model is incomplete. No independent variable had a significant effect on trunk damage. The site has a significant influence on crown dieback and tree vigour. For example, a butternut growing at the Université Laval Agronomy Station is five times more likely to have its crown dieback ranked in the least damaged categories as compared to a butternut growing at Mont SaintBruno (odds ratio 5.2, Table 3). Thus, 79\% of the butternuts at the Agronomy Station exhibited 20\% or less crown dieback compared with only $48 \%$ for the butternuts at Mont SaintBruno. Similarly, the butternuts at the Agronomy Station are 13 times more likely to be ranked healthy (vigour category 1) than if they had grown at Mont Saint-Bruno (odds ratio 12.6, Table 3), such that $63 \%$ of butternuts in Saint-Augustin are healthy, compared to $21 \%$ for Mont Saint-Bruno. The work of Sambaraju et al. (2018) has shown that butternuts in the southwestern part of the province have more trunk damage than those located further north and east. This damage impacts the assessment of their resistance to canker. The same study also showed that butternuts growing at higher altitudes show increased crown dieback. The Mont SaintBruno site is located southwest of the Agronomy Station and at a higher altitude.
Butternuts from which twigs were harvested are five times more likely to be categorized as vigorous (vigour category 1) than those from which no sample was collected. Similarly, they are six times less likely to be assessed as vulnerable (potential resistance, category 0 ) than those which were not sampled (Table 3). Given the random selection of butternuts for sampling, the distinctive features of these butternuts at the beginning of the experiment cannot reasonably explain the impact of twig samples. Our results suggest that these stimulated the physiological reactions of the butternuts that underwent that treatment. Rioux et al. (2018) demonstrated that mechanical injuries, even without pathogen inoculation, can also cause reaction zones to form in the xylem, as these accumulate phenols in a way quite similar than when inoculated. These areas subsequently become covered in new bark. On the other hand, Clark (1955) showed that the pruning of $25 \%$ or $50 \%$ of black walnut twigs (Juglans nigra L.) increased its growth in both diameter and height which, in terms of tree health, may be synonymous with increased resistance to pests. In addition, Jovellar Lacambra et al. (2012) showed that young holm oaks (Quercus ilex L.), from which lower branches had been pruned, had significantly less crown dieback than those that had not been pruned. If there is a cause-and-effect relationship between twig removal, removal 
of dead wood and better health of butternuts, then pruning, pruning for shaping, or any tree work aiming to produce high quality wood (Hubert and Courraud 1994), even if done for aesthetic reasons, could contribute to improve their health, provided that good practices are respected (Thibault 1993; Bureau de normalisation du Québec 2020).

The results of the alternative analysis (logistic regression) for the release experiment are presented in Table 4. As with the initial analysis, no significant effect was found for trunk damage and the results for resistance to canker remained the same. For crown dieback and vigour, the effect of the site remains essentially the same, but the radial growth increment in butternut before crown release significantly influences these two health variables. Thus, for every $2 \mathrm{~mm}$ of growth from 2005 to 2010, butternuts are three times more likely to be rated in a lower crown dieback class than trees with a lower growth. Similarly, butternuts with a theoretically higher growth are three times more likely to be rated in a better vigour class. All models are relevant.

\section{Health data collected by CIME Haut-Richelieu}

Finally, the analysis of butternut health data collected by CIME Haut-Richelieu (Table 5) shows that the canopy layer in which these butternuts are found has a significant impact on trunk damage and potential resistance to canker. Thus, the probability that a butternut has trunk damage on less than $25 \%$ of its circumference decreases by half each time it descends one layer in the forest cover, so $53 \%$ of the dominant trees have $25 \%$ or less of their trunk damaged while $67 \%$ of suppressed butternuts have more than $75 \%$ of the circumference of the trunk affected by canker. Likewise, the probability of a vulnerability to canker doubles with each descent of one layer. In the overstorey, $58 \%$ of butternuts are vulnerable to canker and $42 \%$ show potential resistance, whereas $83 \%$ of suppressed butternuts are vulnerable and only $17 \%$ show resistance.

The phenotype and annual basal area growth have a significant influence on butternut crown dieback. For each jump to a higher category of bark phenotype, from smooth to rough bark, the likelihood that a butternut is in a lower crown dieback class increases by 3.5 times. Due to the significant interaction between phenotype and growth, the latter should be examined for each bark phenotype (Table 5). The annual growth has a significant effect on crown dieback for the smooth bark phenotype ( $\mathrm{P}=0.0045$, Table 6) and for each growth increase of $20 \mathrm{~cm}^{2}$, the probability of the butternut being in the category of lowest occurrence of crown dieback increases by 16 times. The annual growth in basal area has no significant effect on crown dieback in butternuts with intermediate $(\mathrm{P}=0.10)$ or rough $(\mathrm{P}=0.23)$ phenotype bark (Table 6). For their part, Sambaraju et al. (2018) demonstrated that there was a significant difference in butternut crown dieback between bark phenotypes as well as between open grown and dominant butternuts, as compared to suppressed and intermediate butternuts.

Vigour bears a significant relationship to annual growth in basal area $(\mathrm{P}=0.0021$; Table 5). Due to the interactions between growth and phenotype as well as between canopy layer and phenotype, these analyses must be redone for each phenotype. Annual growth in basal area has a significant effect only on butternut with smooth, pale bark $(\mathrm{P}=0.0427$; Table 6). Thus, for each annual increase in basal area of $20 \mathrm{~cm}^{2}$, a butternut is 16 times more likely to be in the top class in terms of vigour than a tree having slower growth. The

Table 4. Sequential logistic regression analysis of the health variables in the butternut increased access to light experiment at Mont Saint-Bruno and the Université Laval Agronomy Station based on the other variables

\begin{tabular}{|c|c|c|c|c|}
\hline \multicolumn{2}{|c|}{ Variables } & \multirow[b]{2}{*}{ Probability } & \multirow[b]{2}{*}{ Odds ratio $^{\mathrm{a}}$} & \multirow{2}{*}{$\begin{array}{l}\text { Residual chi-square } \\
\text { probability }\end{array}$} \\
\hline Dependent & Independent & & & \\
\hline \multirow[t]{4}{*}{ Trunk damage } & Site & 0.55 & - & 0.84 \\
\hline & Samples & 0.33 & - & - \\
\hline & Radial growth ${ }^{\mathrm{b}}$ & 0.91 & - & - \\
\hline & Phenotype & 0.71 & - & - \\
\hline \multirow[t]{4}{*}{ Crown dieback } & Site & 0.0085 & 5.2 & 0.25 \\
\hline & Samples & 0.23 & - & - \\
\hline & Radial growth ${ }^{b}$ & 0.0017 & $3.5^{\mathrm{c}}$ & - \\
\hline & Phenotype & 0.22 & - & - \\
\hline \multirow[t]{4}{*}{ Vigour } & Site & 0.0009 & 10.9 & 0.17 \\
\hline & Samples & 0.084 & - & - \\
\hline & Radial growth ${ }^{\mathrm{b}}$ & 0.0053 & $3.3^{c}$ & - \\
\hline & Phenotype & 0.44 & - & - \\
\hline \multirow[t]{4}{*}{ Resistance } & Site & 0.36 & - & 0.21 \\
\hline & Samples & 0.0271 & 0.16 & - \\
\hline & Radial growth ${ }^{b}$ & 0.0684 & - & - \\
\hline & Phenotype & 0.97 & - & - \\
\hline
\end{tabular}

${ }^{a}$ The odds ratios are given only for significant independent variables $(\mathrm{P} \leq 0.05)$

bRadial growth before release, from 2005 to 2010

${ }^{c}$ For a radial growth increment of $2 \mathrm{~mm}$. Thus, a group of butternuts having a periodic radial growth $2 \mathrm{~mm}$ greater than that of another group will have five times more

chances to be rated in a lower dieback class (e. g., $20 \%$ or less) and to be considered vigorous (class 1 ) 
Table 5. Sequential logistic regression analysis of the butternut health variables collected by CIME Haut-Richelieu

\begin{tabular}{|c|c|c|c|c|}
\hline \multicolumn{2}{|c|}{ Variables } & \multirow[b]{2}{*}{ Probability } & \multirow[b]{2}{*}{ Odds ratio $^{a}$} & \multirow{2}{*}{$\begin{array}{l}\text { Residual chi-square } \\
\text { probability }\end{array}$} \\
\hline Dependent & Independent & & & \\
\hline \multirow[t]{6}{*}{ Trunk damage } & Growth $^{\mathrm{b}}$ & 0.50 & - & 0.78 \\
\hline & Storey & 0.0027 & 0.47 & - \\
\hline & Phenotype & 0.55 & - & - \\
\hline & Growth x Storey & 0.78 & - & - \\
\hline & Growth x Phenotype & 0.61 & - & - \\
\hline & Storey x Phenotype & 0.47 & - & - \\
\hline \multirow[t]{6}{*}{ Crown dieback } & Growth $^{\mathrm{b}}$ & 0.0001 & $14.7^{\mathrm{c}}$ & 0.81 \\
\hline & Storey & 0.80 & - & - \\
\hline & Phenotype & 0.0218 & 3.5 & - \\
\hline & Growth x Storey & 0.89 & - & - \\
\hline & Growth x Phenotype & 0.0322 & - & - \\
\hline & Storey x Phenotype & 0.56 & - & - \\
\hline \multirow[t]{6}{*}{ Vigour } & Growth $^{\mathrm{b}}$ & 0.0021 & $2.3^{\mathrm{c}}$ & 0.04 \\
\hline & Storey & 0.28 & - & - \\
\hline & Phenotype & 0.23 & - & - \\
\hline & Growth x Storey & 0.13 & - & - \\
\hline & Growth $x$ Phenotype & 0.028 & - & - \\
\hline & Storey x Phenotype & 0.036 & - & - \\
\hline \multirow[t]{6}{*}{ Resistance } & Growth $^{\mathrm{b}}$ & 0.40 & - & 0.26 \\
\hline & Storey & 0.0283 & 1.95 & - \\
\hline & Phenotype & 0.46 & - & - \\
\hline & Growth x Storey & 0.80 & - & - \\
\hline & Growth $x$ Phenotype & 0.62 & - & - \\
\hline & Storey x Phenotype & 0.29 & - & - \\
\hline
\end{tabular}

aThe odds ratios are given only for significant independent variables $(\mathrm{P} \leq 0.05)$. The probability that a butternut be in the lowest trunk damage class decreases by $50 \%(0.47)$ and its probability to be sensitive to the canker (resistance 0 ) doubles (1.97) when it is located in a lower storey within the canopy. For each change of bark phenotype class from smooth to rough, the chance that a butternut be rated in a lower dieback class increases by 3.5 times

${ }^{\mathrm{b}}$ The annual growth in basal area, calculated for a time period of 2 to 7 years, depending on the individual butternut being assessed.

${ }^{c}$ For an annual basal area growth of $20 \mathrm{~cm}^{2}$. Taking into account the significant interaction between growth and phenotype for dieback and vigour, these variables are analyzed in Table 6

decreasing likelihood of the canopy layer's impact from smooth- to rough-barked butternut suggests that the layer may have an influence on the latter. However, the low probability of residual chi-squared (Table 3 ) indicates that other factors may also influence vigour.

\section{Diameter at breast height and annual growth in basal area} The analysis of variance $(\mathrm{P}=0.0049)$ and orthogonal comparisons show that the transformed diameter of smooth- and intermediate-bark butternuts is significantly less than that of dark, rough bark trees (Table 7). These results confirm those of Boraks and Broders (2014).

Furthermore, the storey $(\mathrm{P}<0.0001)$ and the bark phenotype $(\mathrm{P}=0.0087)$ have a significant influence on the transformed annual increase in basal area. The interaction between these two variables is not significant $(\mathrm{P}=0.80)$. The least squares means of transformed annual increase in basal area $\sqrt{ }\left(\Delta \mathrm{BA}_{\mathrm{y}}\right)$ and the averages of this increase, $\Delta \mathrm{BA}$, according to storey and bark phenotype, are presented in Table 8. The more dominant the position that butternuts occupy, the greater their growth. All differences in growth among storeys are significant (Table 8).
With higher growth comes low crown dieback and good vigour. The increase of light to which the butternut is exposed through release by pruning treatments (détourage de cime) did not significantly improve tree health. It is possible that the harvesting of twigs and the removal of dead wood, mainly from control butternuts, concealed the effect of the release by pruning treatments. The storey to which the tree belongs has a significant effect on certain health variables. Data from the release study and from CIME Haut-Richelieu suggest that growth is responsible for better health of butternuts. It is also responsible for the dominant position of certain butternuts in the forest cover.

Rough-bark butternuts have a higher $\mathrm{DBH}$ and better annual growth than those with smooth or intermediate bark. We demonstrated the impact of the dark rough-bark phenotype on at least one health variable, but this impact is likely related to the significantly higher growth of these butternuts (Table 8 ). Molecular analyses would be needed to verify whether specific genes determine the presence of this dark, deeply furrowed bark that is found even on small diameter trees (Tables 2) and to check if these genes are also linked to canker resistance. 
Table 6. Logistic regression analysis of the variables of crown dieback and vigour for the butternuts as collected by CIME HautRichelieu according to the phenotype

\begin{tabular}{|c|c|c|c|c|}
\hline \multicolumn{2}{|c|}{ Variables } & \multirow{2}{*}{$\begin{array}{c}\text { Bark } \\
\text { phenotype }\end{array}$} & \multirow[b]{2}{*}{ Probability } & \multirow[b]{2}{*}{ Odds ratio ${ }^{\mathrm{aa}}$} \\
\hline Dependent & Independent & & & \\
\hline Crown dieback & Growth ${ }^{b}$ & $\begin{array}{l}\text { Smooth and pale } \\
\text { Intermediate } \\
\text { Dark and rough }\end{array}$ & $\begin{array}{c}0.0045 \\
0.10 \\
0.23\end{array}$ & $15.8^{\mathrm{c}}$ \\
\hline Vigour & Growth $^{\mathrm{b}}$ & $\begin{array}{l}\text { Smooth and pale } \\
\text { Intermediate } \\
\text { Dark and rough }\end{array}$ & $\begin{array}{c}0.0427 \\
0.07 \\
0.20\end{array}$ & $15.7^{\mathrm{c}}$ \\
\hline Vigour & Story $^{\mathrm{d}}$ & $\begin{array}{l}\text { Smooth and pale } \\
\text { Intermediate } \\
\text { Dark and rough }\end{array}$ & $\begin{array}{l}0.68 \\
0.26 \\
0.12\end{array}$ & \\
\hline
\end{tabular}

The odds ratios are given only for significant independent variables $(\mathrm{P} \leq 0.05)$.

${ }^{\mathrm{b}}$ The annual increment in basal area, for a time period of 2 to 7 years, depending on individual butternuts.

${ }^{c}$ For an annual basal area growth of $20 \mathrm{~cm}^{2}$. The annual growth has a significant effect on crown dieback only for the smooth bark phenotype. For each increase in growth of $20 \mathrm{~cm}^{2}$, the probability that a butternut be rated in the lowest dieback class increases 16 times. A similar effect is observed for vigour.

${ }^{\mathrm{d}}$ The effect of the story on vigour tends to increase on butternuts with dark rough bark, without being statistically significant.

Thus, our results suggest, that as part of a selection program for butternuts which are resistant to canker caused by O. clavigignenti-juglandacearum (Environment Canada 2010), individuals with stronger growth should be favoured. The overstorey and the rough bark phenotype are good indicators of the higher growth of a butternut.

It would be relevant for an experiment to be conducted comparing released butternut trees to pruned butternuts and others without intervention, to clarify the impact of these two silvicultural practices on butternut health and survival. Mohni et al. (2009) report that the English walnut (Juglans regia L.) in plantations with closed canopies reacts slowly when the cover is released. Stringer and Wittwer (1985) showed that black walnut reacted up to 12 years after thinning. Longer term monitoring of the butternut observed in the release experiment would therefore be appropriate, as the reaction to release treatments can be delayed by more than five years.

\section{Acknowledgments}

The authors thank Hugues Sansregret, Charles Villeneuve, André Lapierre and Julie Bouliane from Université Laval; Robert Werbiski from the National Defence, and Valérie Deschênes and Renée Gagnon from CIME Haut-Richelieu for their support in this work. We also thank Martine Blais and Caroline Bourdon from the Canadian Forest Service of Natural Resources Canada for collecting health data for this project, and Lauriane Monette, Valérie Deschêsnes, MarieFrance Côté, Patrick Laniel, Maxime Tremblay, Camille Pelletier-Guittier, Laurence Teyssier, Yolande Boyer, Diane Ravit, Maxime Quesnel, Marie-Pier Prairie, Élise Carpentier, Marie-Pier Lavallée, Pierre Jackson and Étienne Drouin for monitoring butternuts at CIME Haut-Richelieu sites.

Our thanks also go to Environment Canada's Interdepartmental Recovery Fund and the Department of National Defence for funding this project, as well as to the Rêverie Foundation for the scholarship awarded to Nicolas NadeauThibodeau.
Table 7. Least square means of the square root of the final diameter, $\sqrt{ }\left(\mathrm{DBH}_{\mathrm{f}}\right)$ and averages of these $\mathrm{DBH}_{\mathrm{f}}$, according to bark phenotype for the data submitted by CIME Haut-Richelieu

\begin{tabular}{lcc}
\hline Phenotype & $\begin{array}{c}\text { Least square means } \\
\text { of } \sqrt{ }\left(\mathrm{DBH}_{\mathbf{f}}\right)\end{array}$ & $\begin{array}{c}\text { Mean } \mathbf{D B H}_{\mathrm{f}} \\
(\mathbf{c m})\end{array}$ \\
\hline Smooth and pale & $4.3 \mathrm{~b}$ & 20.1 \\
Intermediate & $4.1 \mathrm{~b}$ & 18.7 \\
Dark and rough & $5.4 \mathrm{a}$ & 32.2 \\
\hline
\end{tabular}

${ }^{\mathrm{a}}$ Least square means followed by a different letter are significantly different according to the orthogonal comparisons made on these variables $(\mathrm{P} \leq 0.05)$

Table 8. Least square means of the square root of annual increase in basal area $\sqrt{ }\left(\Delta \mathrm{BA}_{\mathrm{y}}\right)$ and averages of this increase, $\triangle \mathrm{BA}_{\mathrm{y}}$, based on storey and bark phenotype for data submitted by CIME Haut-Richelieu

\begin{tabular}{|c|c|c|}
\hline Category & $\begin{array}{c}\text { Least square means }{ }^{\mathrm{a}} \\
\text { of } \sqrt{ }\left(\Delta \mathrm{B} \mathrm{A}_{\mathrm{y}}\right)\end{array}$ & $\begin{array}{l}\text { Average } \Delta \mathrm{BA}_{\mathrm{y}} \\
\left(\mathrm{cm}^{2}\right)\end{array}$ \\
\hline \multicolumn{3}{|l|}{ Storey } \\
\hline Overstory & $5.2 \mathrm{a}$ & 29.7 \\
\hline Co-dominant & $3.6 \mathrm{~b}$ & 15.7 \\
\hline Intermediate & $2.4 \mathrm{c}$ & 5.9 \\
\hline Suppressed & $1.0 \mathrm{~d}$ & 0.6 \\
\hline \multicolumn{3}{|l|}{ Phenotype } \\
\hline Smooth & $2.4 \mathrm{~b}$ & 8.5 \\
\hline Intermediate & $2.9 \mathrm{~b}$ & 13.2 \\
\hline Dark and rough & $3.8 \mathrm{a}$ & 25.8 \\
\hline
\end{tabular}

${ }^{\text {aF }}$ or each variable, least square means followed by a different letter are significantly different, according to the orthogonal comparisons made on these variables $(\mathrm{P} \leq 0.05)$ 


\section{References}

Abgrall, J.F. and A. Soutrenon. 1991. La forêt et ses ennemis, $3^{\text {ème }}$ édition. Grenoble, CEMAGREF, pp. 147-150, 247-250, 377-380.

Amorini, E., M.C. Manetti, T. Turchetti, A. Sansotta and F. Villani. 2001. Impact of silvicultural system on Cryphonectria parasitica incidence and on genetic variability in a chestnut coppice in Central Italy. For. Ecol. Manag. 142: 19-31.

Boraks, A. and K.D. Broders. 2014. Butternut (Juglans cinerea) health, hybridization, and recruitment in the northeastern United States Can. J. For. Res. 44: 1244-1252. dx.doi.org/10.1139/cjfr-2014-0166 Broders, K.D. and G.J. Boland. 2011. Reclassification of the butternut canker fungus, Sirococcus clavigignenti-juglandacearum into the genus Ophiognomonia. Fungal Biol. 115: 70-79. doi:10.1016/j.funbio.2010.10.007

Broders, K.D., A. Boraks, A.M. Sanchez and G.J. Boland. 2012. Population structure of the butternut fungus, Ophiognomonia clavigignenti-juglandacearum, in North American forests. Ecol. Evol. 2: 2114-2127.

Bureau de normalisation du Québec. 2020. Norme NQ 0605200/2001 Entretien arboricole et horticole, $2^{\mathrm{e}}$ édition révisée. SainteFoy, Québec, pp. 15-30, 81-97.

Clark, F.B. 1955. Black walnut responds to pruning. J. For. 53: 362 365.

Corneil, J.A. and L.F. Wilson. 1979. Life history of the butternut curculio, Conotrachelus juglandis (Coleoptera: Curculionidae), in Michigan. Great Lakes Entomol. 12: 13-15.

Davis, C.N., Myren, D.T. and E.J. Czerwinski. 1992. First report of butternut canker in Ontario. Plant Dis. 76: 972.

D’Eon, S.P., L.P. Magasi, D. Lachance and P. DesRochers. 1995. DNARPA, Réseau national de surveillance de l'état de santé des forêts au Canada : Guide d'établissement et de surveillance des parcelles (version revue). Rapport d'information Pi-X-117F, Chalk River, Ontario, $107 \mathrm{pp}$.

DesRochers, P., D. Cloutier, J. Bérubé, M. Blais, K. Savard and J. Thibault. 2010. État de santé du noyer cendré (Juglans cinerea L.) sur les terres fédérales au Québec en 2006-2008. Ressources naturelles Canada, Service canadien des forêts, Centre de foresterie des Laurentides, Rapport interne, 70 pp.

Environnement Canada. 2010. Programme de rétablissement du noyer cendré (Juglans cinerea) au Canada. Série de Programmes de rétablissement de la Loi sur les espèces en péril, Environnement Canada, Ottawa, vii + 29 pp

Farrar, J.L. 1996. Les arbres du Canada. Fides, Saint-Laurent (QC) et Service canadien des forêts, Ottawa Ontario, 502 pp.

Farris, M. and J. Appleby. 1979. The biology of the walnut caterpillar, Datana integerrima, In: Proceedings of the North Central Branch, Entomological Society of America, 33: 50.

Furnier, G.R., A.M. Stolz, R.M. Mustaphi and M.E. Ostry. 1999. Genetic evidence that butternut canker was recently introduced into North America. Can. J. Bot. 77: 783-785.

Grandtner, M.M. 1966. La végétation forestière du Québec méridional - 7 e tirage, 1981. Québec, Le Presses de l'Université Laval, 216 pp. Graves, A.H. 1923. The Melanconis disease of the Butternut (Juglans cinerea L.). Phytopathology 13: 411-434.

Harrison, K.J., J.E. Hurley and M.E. Ostry. 1998. First report of butternut canker caused by Sirococcus clavigignenti-juglandacearum in New Brunswick, Canada. Plant Dis. 82: 1282.

Hubert, M. and R. Courraud. 1994. Élagage et taille de formation des arbres forestiers, $2^{\mathrm{e}}$ édition. Institut pour le développement forestier, Paris, $303 \mathrm{pp}$.

Innes, L. and A. Rainville. 1996. Distribution et détection du Sirococcus clavigignenti-juglandacearum au Québec. Phytoprotection 77: 75-78. http://id.erudit.org/iderudit/706102ar.

Jacobi, W.R., P. Pineda Bovin, K.S. Burns, A. Crump and B.A. Goodrich. 2017. Pruning limber pine to reduce impacts from white pine blister rust in the Southern Rocky Mountains. For. Sci. 63: 218224. https://doi.org/10.5849/forsci.16-011.
Jovellar Lacambra, L.C., A. Garcia Martin and R. San Martin Fernandez. 2012. Effects of microsite conditions and early pruning on growth and health status of holm oak plantations in Central-Western Spain. New Forests 43: 887-903. https://doi.org/10.1007/ s11056-012-9335-7

Kuntz, J.E., A.J. Prey, S. Jutte and V.M.G. Nair. 1979. The etiology, distribution, epidemiology, histology and impacts of butternut cancer in Wisconsin. In: Walnut insects and diseases. Workshop proceedings, June 13-14, 1978. Gen. Tech. Rept. NC-52, USDA For. Serv., pp. 69-72.

Laflamme, G. 1999. Traitement réussi d'une plantation de pins rouges affectée par le Gremmeniella abietina, race européenne. Phytoprotection 80: 55-64. https://doi.org/10.7202/706180ar.

Lupien, P. 2006. Des feuillus nobles en Estrie et au Centre-duQuébec - Guide de mise en valeur. Association forestière des Cantons de l'Est, Sherbrooke, pp. 24-25 et 116-120.

Lupien, P. 2013. Le noyer cendré. In Ministère des Ressources Naturelles. Le guide sylvicole du Québec, Tome 1, Les fondements biologiques de la sylviculture, ouvrage collectif sous la supervision de B. Boulet et M. Huot, Les Publications du Québec, pp 68-69.

Majcen, Z. 1995. Le noyer cendré au lac Tapani. Note de recherche forestière no 64. Direction de la recherche forestière, ministère des Ressources naturelles, Sainte-Foy (Québec). 5 pp.

McIlwrick, K., Wetzel, S., Beardmore, T. and K. Forbes. 2000. Ex situ conservation of American chestnut (Castanea dentata (Marsh.) Borkh.) and butternut (Juglans cinerea L.), a review. For. Chron. 76: 765-774.

Michler, C.H., P.M. Pijut, D.F. Jacobs, R. Meilan, K.E. Woeste and M.E. Ostry. 2006. Improving disease resistance of butternut (Juglans cinerea), a threatened fine hardwood: A case for single-tree selection through genetic improvement and deployment. Tree Physiol. 26: 121-128.

Millers, I., D. Lachance, W.G. Burkman and D.C. Allen. 1991. North American sugar maple decline project: Organization and field methods. USDA For. Serv. Northeast. For. Exp. Stn. Gen. Tech. Rep. NE-154/Forestry Canada, 26 pp.

Mohni, C., F. Pelleri and G.E. Hemery. 2009. The modern silviculture of Juglans regia L.: A literature review. Die Bodenkultur 60: 21-34. Nadeau-Thibodeau, N. 2015. Le chancre causé par l'Ophiognomonia clavigignenti-juglandacearum : protection et rétablissement du noyer cendré. Université Laval, Faculté des études supérieures et postdoctorales, Mémoire de maîtrise, $119 \mathrm{pp}$.

Nair, V.M.G., C.J. Kostichka and J.E. Kuntz. 1979. Sirococcus clavigignenti-juglandacearum: an undescribed species causing canker on butternut. Mycologia 71: 641-645.

Nielsen, C., M. Cherry, B. Boysen, A. Hopkin, J. McLaughlin and T. Beardmore. 2003. Évaluation et rapport de situation du COSEPAC sur le noyer cendré (Juglans cinerea) au Canada. Comité sur la situation des espèces en péril au Canada, Ottawa, 37 pp.

Niinemets, $\ddot{U}$. and F. Valladares. 2006. Tolerance to shade, drought, and waterlogging of temperate northern hemisphere trees and shrubs. Ecol. Monog. 76: 521-547.

Orchard, L.P., J.E. Kuntz and K.J. Kessler. 1982. Reactions of Juglans species to butternut canker and implications for disease resistance. In: Proceedings of the Black walnut for the Future: Gen. Tech. Rep. NC-74. USDA For. Serv. North Central For. Exp. Stn., St. Paul, MN. pp. 27-31.

Ostry, M.E. 1997. Butternut canker: history, biology, impact, and resistance. In: Knowledge for the future of black walnut. Proceedings of the 5th black walnut symposium, Sambeek, J.W. van, (ed.), July 28-31, 1996, Springfield, MO, USDA For. Serv. NC-191, pp. 192-199.

Ostry, M.E. and K. Woeste. 2004. Spread of butternut canker in North America, host range, evidence of resistance within butternut populations and conservation genetics. In: Black Walnut in a new century. Proceedings of the $6^{\text {th }}$ Walnut Council research symposium, C.H. Michler, P.M. Pijut, J.W. Sambeek, M.V. van, Cogge- 
shall, J. Seifert, K. Woeste, R. Overton and F. Ponder Jr. (Eds), July 25-28, Lafayette, IN. Gen. Tech. Rep., St. Paul, MN, USDA For. Serv. NC-243, pp. 37-44.

Ostry, M.E., M. Mielke and D. Skilling. 1994. Butternut - Strategies for managing a threatened tree. Gen. Tech. Rep. NC-165. St. Paul, MN: USDA Forest Service, North Central Forest Experimental Station, $7 \mathrm{pp}$

Ostry, M.E., B. Ellingson, D. Seekins and W. Ruckheim. 2003. The need for silvicultural practices and collection of butternut germplasm for species conservation. In: Proceedings of the 13th Central Hardwood Forest Conference. J.W. Van Sambeek, J.O. Dawson, F. Ponder, Jr., E.F. Loewenstein and J.S. Fralish, (Eds.). Gen. Tech. Rep. NC-234. USDA Forest Service, North Central Experiment Station, St. Paul, MN, USA, pp. 551-555.

Pitt, D., D. Weingartner and S. Greifenhagen. 2001. Precommercial thinning of trembling aspen in northern Ontario: Part 2 - Interactions with Hypoxylon canker. For. Chron. 77: 902-910.

Rink, G. 1990. Juglans cinerea L. Butternut. In: Silvics of North America. Vol. 2 Hardwoods, Burns, R.M. and Honkala, B.H. (tech. coord.), USDA For. Serv. Agr. Hdbk, pp. 386-390.

Rioux, D., P. Tanguay, K. Sambaraju, N. Nadeau-Thibodeau and P. DesRochers. 2019. L'histoire d'un chancre menaçant d'exterminer le noyer cendré. Nat. Can. 143: 39-48. https://doi.org/ 10.7202/1060054ar

Rioux, D., M. Blais, N. Nadeau-Thibodeau, M. Lagacé, P. DesRochers, K. Klimaszewska and L. Bernier. 2018. First extensive microscopic study of butternut defense mechanisms following inoculation with the canker pathogen Ophiognomonia clavigignentijuglandacearum reveals compartmentalization of tissue damage. Phytopathology 108: 1237-1252.

Sambaraju, K.R., P. DesRochers and D. Rioux. 2018. Factors influencing the regional dynamics of butternut canker. Plant Dis. 102: 743-752.
SAS Institute. 2008. SAS/STAT 9.2 User's Guide - The GLM Procedure (Book Excerpt). Cary, NC SAS Institute Inc., 208 pp.

SAS Institute. 2011. SAS/STAT 9.3 User's Guide. Cary, NC, SAS Institute Inc. pp. 4033-4267.

Sinclair, W. and H. Lyon. 2005. Sirococcus canker of butternut. In: Diseases of trees and shrubs. Second edition, Cornell University Press, N.Y., 116 pp.

Stringer, J.W. and R.F. Wittwer. 1985. Release and fertilization of black walnut in natural stands. In: Dawson, O.J. and A.K. Majerus (Eds.). Proceedings of the 5th Central hardwood forest conference. University of Illinois, Urbana-Champaign, IL, United States, pp. 62-67.

Stokes, M.E., C.H. Davis and G.G. Koch. 1995. Categorical data analysis using the SAS system. Cary, NC, SAS Institute Inc. pp. 163246.

Tanguay, P., M. Blais, A. Potvin, D. Stewart, D. Walker, N. Nadeau-Thibodeau, P. DesRochers and D. Rioux. 2018. qPCR quantification of Ophiognomonia clavigignenti-juglandacearum from infected butternut trees under different release treatments. For. Pathol. 48, 13 pp. https://doi.org/10.1111/efp.12418

Thibault, M. 1993. Guide du soin des arbres. Saint-Laurent, Montréal, Éditions du Trécarré, pp. 107-119.

Weber, R.W.S. 2014. Biology and control of the apple canker fungus Neonectria ditissima (syn. N. galligena) from a Northwestern European perspective. Erwerbs-Obstbau 56: 95-107. https:// doi.org/10.1007/s10341-014-0210-X

Woeste, K.E., L. Farlee, M.E. Ostry, J.R. McKenna and S. Weeks. 2009. A Forest Manager's Guide to Butternut. North. J. Appl. For. 26: 9-14. 